\title{
Strategies to transplant Fabaceae species from natural regeneration
}

\author{
Luana Cristielle Araújo Silva ${ }^{1} \odot$, Gleica Candido Santos ${ }^{1 *}{ }^{\circ}$, Israel Marinho Pereira ${ }^{1} \odot$, \\ Michele Aparecida Pereira da Silva ${ }^{1} \odot$, Marcio Leles Romarco de Oliveira ${ }^{1} \odot$, Miranda Titon $^{1} \odot$ \\ ${ }^{1}$ Universidade Federal dos Vales do Jequitinhonha e Mucuri, Diamantina, MG, Brasil. E-mail: Iuana.araujoflorestal@gmail.com; gleicacandidosantos@gmail.com;
imarinhopereira@gmail.com; michelesilva04@yahoo.com.br; marcioromarco@gmail.com; mirandatiton@gmail.com
}

ABSTRACT: The objective of this study was to test the effect of shading levels and leaf reduction intensities on the survival and growth of Copaifera langsdorffii Guillem. ex Benth., Copaifera langsdorffii Desf. and Hymenaea courbaril L. seedlings rescued from natural regeneration. Three experiments were conducted in a completely randomized design with split-plots, in which four shading composed the plots ( 0 or full sun; 30; 50; and 70\%) and three leaf reductions intensities composed the subplots $(0 ; 50$; and $100 \%$ ). General average survival after six months from the rescue was $47.6 \%$ for $C$. tomentosum, $44.6 \%$ for $H$. courbaril and $21.4 \%$ for $C$. langsdorffii. Considering the height, only $C$. tomentosum demonstrated a significant effect of leaf reduction and shading, with total or partial maintenance of leaves ( $0 \%$ or $50 \%$ of leaf reduction) and the when under up to $50 \%$ shading providing a greater increment. Leaf reduction is not necessary for rescuing the seedlings from $\mathrm{H}$. courbaril and $\mathrm{C}$. langsdorffii, whereas the leaf reduction of $50 \%$ intensity is advised to enhance the survival of $C$. tomentosum species. As for shading, $50 \%$ is the most suitable level for acclimatization of $H$. courbaril and $\mathrm{C}$. tomentosum seedlings while for $\mathrm{C}$. langsdorffii the level is $70 \%$.

Key words: Copaifera langsdorffii; Centrolobium tomentosum; flora rescue; Hymenaea courbaril; mitigation measures

\section{Estratégias para transplantio de espécies de Fabaceae provenientes da regeneração natural}

RESUMO: Este trabalho teve como objetivo avaliar o efeito de diferentes sombreamentos e reduções da lâmina foliar na sobrevivência e crescimento de mudas das espécies Copaifera langsdorffii Guillem. ex Benth., Copaifera langsdorffii Desf. e Hymenaea courbaril $\mathrm{L}$. provenientes do resgate da regeneração natural. Três experimentos foram conduzidos em delineamento inteiramente casualizado, em parcelas subdivididas, cujas parcelas foram quatro níveis de sombreamento ( 0 ou pleno sol, 30 , 50 e $70 \%$ e as subparcelas três intensidades de redução foliar (0,50 e $100 \%)$. A sobrevivência média geral após seis meses do resgate foi de $47,6 \%$ para a espécie $C$. tomentosum, 44,6 \% para $H$. courbaril e 21,4\% para $C$. langsdorffii. Para a altura, apenas $C$. tomentosum apresentou efeito significativo da redução foliar e do sombreamento, sendo que a manutenção total ou parcial das folhas (0\% ou $50 \%$ de redução foliar) e o acondicionamento sob até $50 \%$ de sombra proporcionaram maior incremento. Para o resgate de plantas jovens de $\mathrm{H}$. courbaril e $\mathrm{C}$. langsdorffii não há necessidade de realizar a redução foliar, já para a espécie $C$. tomentosum recomenda-se a redução foliar de $50 \%$ de intensidade, visando potencializar a sobrevivência. Quanto ao sombreamento, 50 \% é o nível mais indicado para aclimatação de mudas de H. courbaril e C. tomentosum, e $70 \%$ para a espécie $C$. langsdorffii.

Palavras-chave: Copaifera langsdorffii; Centrolobium tomentosum; salvamento da flora; Hymenaea courbaril; medidas mitigadoras

* Gleica Candido Santos - E-mail: gleicacandidosantos@gmail.com (Corresponding author)

Associate Editor: Ricardo Gallo 


\section{Introduction}

The rescue technique of seedlings and young individuals from natural regeneration is a promising alternative for increasing the diversity and availability of seedlings in forest nurseries, especially when aiming at the restoration of degraded areas. This very technique can reduce nursery costs since it cuts off burdensome steps of seed processing such as the collection, processing and storage (Viani \& Rodrigues, 2007). Moreover, rescuing rare or endangered species allows the conservation of genetic material that otherwise would be suppressed, as well as avoids the limitation of the seedling production, via seminal, for species with low seed germination (Calegari et al., 2011).

Even though rescuing endangered flora is a mitigating measure recommended by environmental agencies for minimizing the negative impacts of vegetation suppression (Brasil, 2009), some bottlenecks still separate the legal aspect and the compatibility of implementing this technique on a large scale. Absence of specific methodologies for the native species range is the main obstacle, since these ensure the survival and quality of plants after the rescue (Santos, 2018).

Studies concerning the rescue of seedlings and young individuals have found that native species demonstrate different behaviors and survival rates (Viani \& Rodrigues, 2007; Viani et al., 2012). Depending on the rescue methodology adopted, the response of the same species may vary completely (Viana et al., 2015) or be not necessarily influenced (Zimmermann et al., 2017). Therefore, given the importance of the rescue, considering the germplasm rescue in areas intended for suppression, and due to the high diversity of native species occurring in Brazilian biomes, it is necessary to conduct studies that include less-investigated species (Silva et al., 2017).

In this study, we worked with the species Centrolobium tomentosum Guillem. ex Benth., Copaifera langsdorffii Desf. and Hymenaea courbaril L., all part of the Fabaceae family, having wide distribution over the Brazilian territory (Klitgaard, 2015; Queiroz et al., 2015; Lima \& Pinto, 2015). $C$. langsdorffii and $H$. courbaril species fall into the ecological group of late secondary, while $C$. tomentosum is considered as early secondary, boasting a faster growth than the other abovementioned species (Almeida et al., 2010).

Studies on flora rescue focused on the Fabaceae are extremely relevant because the species of this family, among other factors, have the notorious ability of establishment in sites with different degradation levels, meaning that they exhibit high potential to be used in ecological restoration (Silva et al., 2018). This aptitude is constantly related to the symbiosis that most of its species are able to establish with nitrogen-fixing bacteria and mycorrhizal fungi (Moreira \& Siqueira, 2006).

Partially cutting the leaves is a practice that can be used during the plant rescue procedure (Viani \& Rodrigues, 2007) in order to help the success of the seedling establishment by reducing water stress, besides facilitating the visualization of the emission of new leaves (Silva et al., 2015). However, when it comes to native species, little is known about the efficiency of this method and even if it is necessary at all (Viani et al., 2012; Santos et al., 2019).

Light intensity, temperature, $\mathrm{CO}_{2}$ concentration and soil moisture are the factors that affect photosynthetic activity and, consequently, influence plant growth (Pierezan et al., 2012). According to Pierezan et al. (2012), light is paramount, not only providing energy for photosynthesis, but also the signals that regulate plant growth. The response to different conditions of incident light is something intrinsic to each native species, and can vary considerably according to the plasticity degree and dependence on the quantity or quality of light (Pacheco \& Paulilo, 2009).

Thereby, specific studies are needed to elucidate both the behavior of the species when placed under different shading levels (Sabino et al., 2016), based on the reduction or of the leaf blades. With this type of information, enhancing the quality and survival of the rescued seedlings is possible as well as reducing costs, both fundamental characteristics for dissemination of the rescue technique.

In light of the foregoing, this research aimed to study the effects of leaf reduction as well as the shading level on the survival and growth of seedlings from Centrolobium tomentosum, Copaifera langsdorffii and Hymenaea courbaril rescued from natural regeneration, aiming at their later use in forest restoration projects.

\section{Materials and Methods}

Young plants of $C$. tomentosum, C. langsdorffii and $H$. courbaril used in this study were rescued from the understory of a Semideciduous Seasonal Forest located within Campus do Moura Experimental Farm (18 $49^{\prime} 18.63^{\prime \prime} S$ and $44^{\circ} 24^{\prime} 5.20^{\prime \prime} \mathrm{W} ; 715 \mathrm{~m}$ of mean altitude), part of the Federal University of Jequitinhonha and Mucuri Valleys (UFVJM), located in the municipality of Curvelo, Minas Gerais, Brazil. Climate of the area is of the Aw type, as according to Köppen classification, tropical with dry winter (Sá Junior et al., 2012); with mean temperatures of approximately $28{ }^{\circ} \mathrm{C}$ and the rainfall index around $1200 \mathrm{~mm}$ year ${ }^{-1}$, mostly concentrated during summer.

Rescue took place during the rainy season, respecting the seedling bank supply, with 168 young plants obtained from each of the three studied species, thus totaling 504 individuals. Mean height at the rescue was of $4.9 \mathrm{~cm}$ for $C$. langsdorffii, 9.4 $\mathrm{cm}$ for $C$. tomentosum, and $20.9 \mathrm{~cm}$ for $\mathrm{H}$. courbaril. During the collection procedure, we used a gardening spade to remove the plants from the soil, which were manually crushed in order to obtain the bare root, placed afterwards in containers with water and kept in this condition during transportation.

Approximately $12 \mathrm{~h}$ after collection, three experiments were set up (one for each species) in the hardening area of the nursery from the Forestry Department of UFVJM (18 $12^{\prime} 07^{\prime \prime} \mathrm{S}$ and $43^{\circ} 34^{\prime} 20^{\prime \prime} \mathrm{W}$; $1400 \mathrm{~m}$ of altitude), located in Diamantina, Minas Gerais, Brazil, 130 km apart from 
the rescue area. According to the Köppen classification, the climate of Diamantina is of Cwb type, characterized by both mild and humid summers and cooler and drier winters (Sá Junior et al., 2012). Annual precipitation means vary between 1250 and $1550 \mathrm{~mm}$, with temperature between 18 and $19^{\circ} \mathrm{C}$.

We conducted the experiments in an entirely randomized design, in split-plots, with plots established by four shading levels ( 0 or full sun; $30 ; 50$; and $70 \%$ ) and subplots by three leaf reduction intensities (0; 50; and $100 \%)$, with 14 replicates. One plant per tube consisted the used experimental unit. All individuals were transplanted into $280 \mathrm{~cm}^{3}$ tubes filled with a substrate composed of $70 \%$ vermiculite and $30 \%$ rice husk ash, plus $3 \mathrm{~g} \mathrm{~L}^{-1}$ of Osmocote ${ }^{\circledR}$ (14-14-14). Irrigation took place five times a day, via micro-sprinklers.

First measurements of height $(\mathrm{cm})$ and diameter $(\mathrm{mm})$ took place after the transplanting. Height was obtained with the aid of a graduated ruler, by considering it as the distance from the plant collar to the insertion of the last bud; as for obtaining the collar diameter, digital calipers were used, with precision in millimeters.

After six months, data was collected once again and then the increments in height and diameter were obtained, given by the difference in the measurement at six months compared to the initial one. At the end of this period, the survival percentage and the number of emission of new leaves were also obtained.

Data on the height and diameter increments as well as on emission of new leaves were subjected to analysis of variance. In case of significant difference among treatments, the means were compared by using the Tukey Test at $5 \%$ significance, through the R software ( $R$ Core Team, 2018). As for the survival, we present the descriptive analysis of the data.

\section{Results and Discussion}

\section{Survival}

General mean survival, six months after rescue, was of $47.6 \%$ for Centrolobium tomentosum, $21.4 \%$ for Copaifera langsdorffii and $44.6 \%$ for Hymenaea courbaril. Regarding the shading levels, $C$. tomentosum had 38.1, 21.4, 85.7 and $45.2 \%$ survival for $0,30,50$ and $70 \%$ shading levels, respectively. $C$. langsdorffii species obtained $2.4,19.0,23.8$, and $40.5 \%$ while the $H$. courbaril species had $33.3,38.1,59.5$, and $47.6 \%$ for the levels of $0,30,50$ and $70 \%$ shading, respectively. For leaf reduction intensity, the species $C$. tomentosum, $C$. langsdorffii and $H$. courbaril had 44.6, 64.3, $33.9 \% ; 41.1,21.4,1.8 \%$ and $53.8,39.3$ and $41.1 \%$ survival for leaf reductions of 0,50 and $100 \%$, respectively (Figure 1).

There was a great variation in survival for all studied species, even within the same treatment. C. langsdorffii demonstrated a greater sensitivity tendency to the rescue procedure, corroborated by the mortality rate of $97.6 \%$ of the seedlings placed under full sun and $98.2 \%$ of those that had their leaf blades completely removed. This behavior emphasizes the importance of placing $C$. langsdorffii individuals under shading during the after-rescue period, also indicating that leaf reduction at a $100 \%$ intensity is not advised for this species.

Viani \& Rodrigues (2007) rescued plants of C. tomentosum and $C$. langsdorffii, from different height classes, and placed them under a $50 \%$ shading, obtaining the overall survival of $88.9 \%$ and $21.7 \%$, respectively. In our study, we have observed similar results to those abovementioned under the $50 \%$ shading, where the overall survival was of $85.7 \%$ for $C$. tomentosum and $23.8 \%$ for $C$. langsdorffii. This emphasizes the existence of differentiated tolerance among the studied species in relation to the stresses arising from using the seedling rescue technique during seedling production.

The survival observed for $H$. courbaril was compatible with its ability in adapting to a wide range of the light spectrum as described by Dutra et al. (2015) in the seedling production via seminal. C. langsdorffii had a response similar to that reported by Dutra et al. (2012), in which a greater seedling survival was observed for this species when shading increased in comparison to the full sun treatment. However, Reis et al. (2016) reinforce that extreme shading levels (full sun and $90 \%$ shading) should be avoided in the production of $C$. langsdorffii seedlings.

We have found that the $50 \%$ shading enhanced the survival of C. tomentosum (85.7\%) and H. courbaril (59.5\%), while for $C$. langsdorffii, we oberseved this behavior under $70 \%$ shading (40.5\%). According to Viani \& Rodrigues (2007), acclimation performed under shading reduces the negative impacts after transferring the rescued individuals, thus mitigating factors such as the solar radiation and temperature. Shading is also favorable from the physiological point of view, especially for non-pioneer species, as they are more susceptible to photoinhibition (Silvestrini et al., 2007). Hence, we recommend acclimating $H$. courbaril and $C$. tomentosum seedlings under $50 \%$ shading. For $C$. langsdorffii, the level of $70 \%$ shading is advisable for its acclimation in nursery, providing a greater number of living individuals for subsequent planting in forest restoration projects.

When analyzing the leaf reduction factor, possibly the total or partial permanence of the leaves was positive in the seedling survival of all evaluated species. According to Xavier et al. (2013), the presence of leaves is closely tied to root formation, since these are the organs where the carbohydrates needed for rhizogenesis are synthesized, as well as the essential hormones for this said process, such as the auxins.

Aiming to increase the survival of rescued individuals, we deemed as unnecessary performing the leaf reduction in seedlings of $H$. courbaril and $C$. langsdorffii, thus promoting a reduction in the operational cost of the rescue procedure. For $C$. tomentosum, we recommend reducing the leaf blade by $50 \%$, in order to increase survival after six months of the transplanting. 
Centrolobium tomentosum
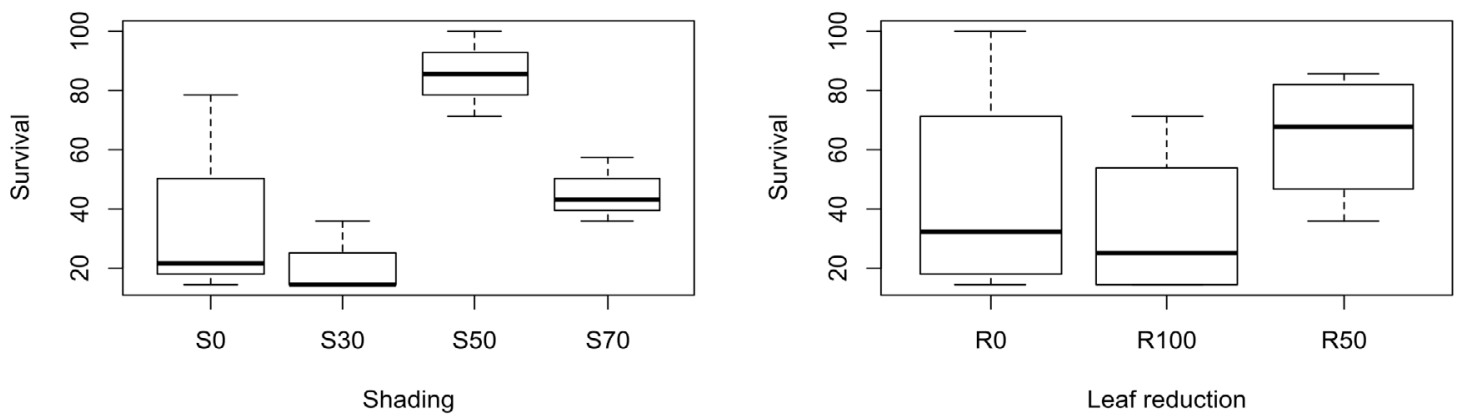

Copaifera langsdorffii
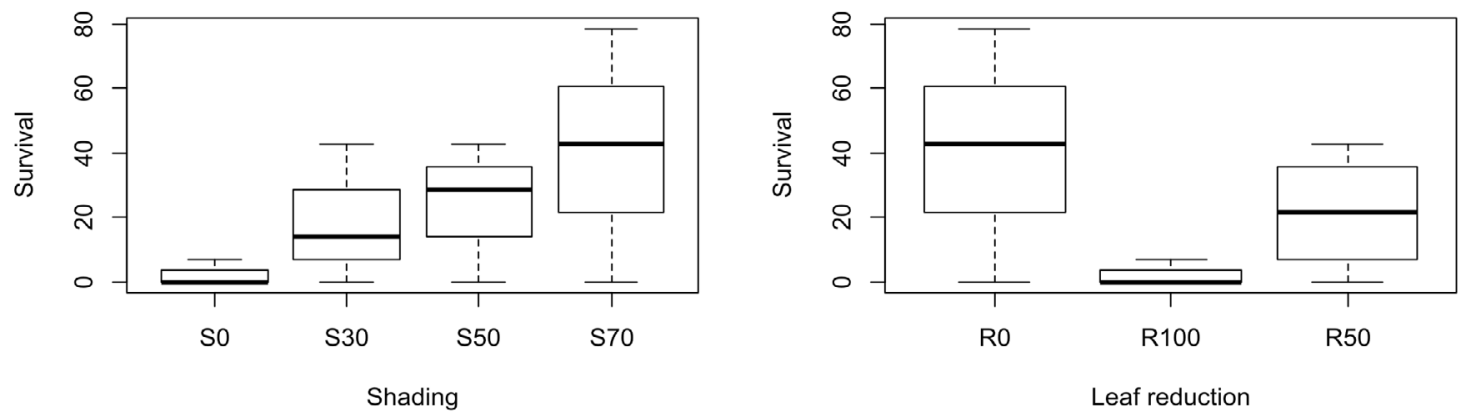

Hymenaea courbaril
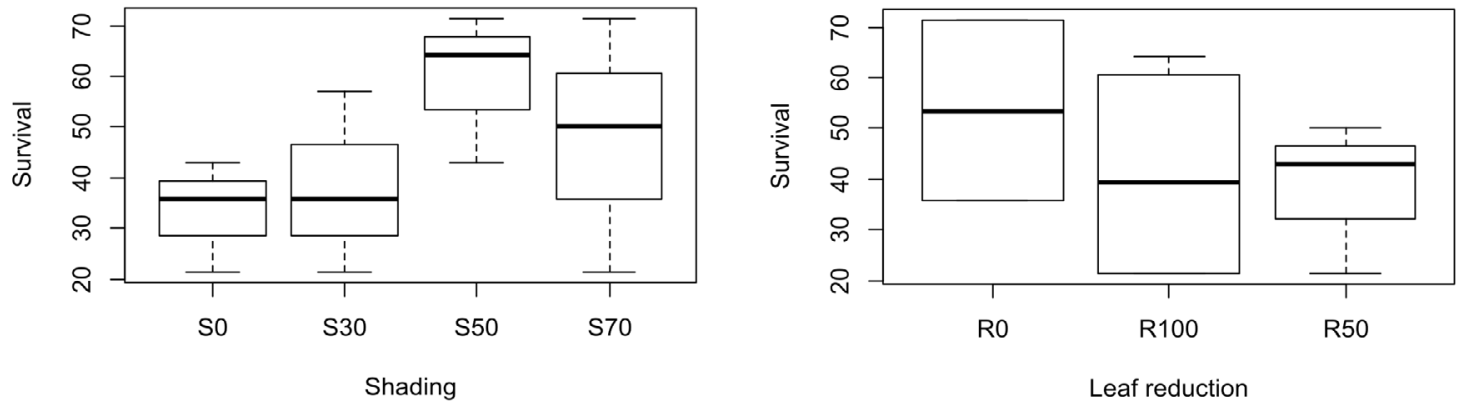

Figure 1. Nursery survival boxplot of seedlings from the species $\mathrm{C}$. tomentosum, C. langsdorffii and $H$. courbaril obtained through natural regeneration, according to different shading levels (SO=Full sun; S30=30\%; S50=50\%; and S70=70\% shading) and leaf reduction intensities ( $\mathrm{R} 0=$ No reduction; $\mathrm{R} 50=50 \%$; and $\mathrm{R} 100=100 \%$ of leaf reduction), after six months from the rescue.

\section{Height, diameter, and emission of new leaves}

Concerning the variable height increment, there was no interaction between tested factors (shading $\mathrm{x}$ leaf reduction), for none of the evaluated species. When analyzing the factors alone, only the species $C$. tomentosum had a significant effect of leaf reduction and shading for this variable (Table 1).

Table 1. Height and diameter increments in plants of Centrolobium tomentosum, Copaifera langsdorffii and Hymenaea courbaril at six months after their rescue. Plants were subjected to three leaf reduction levels (0; 50; and 100\%) and placed under four different shadings (0; 30; 50; and 70\%).

\begin{tabular}{|c|c|c|c|c|c|c|c|c|c|}
\hline \multirow[b]{2}{*}{ Treatments } & \multicolumn{3}{|c|}{ Centrolobium tomentosum } & \multicolumn{3}{|c|}{ Copaifera langsdorffii } & \multicolumn{3}{|c|}{ Hymenaea courbaril } \\
\hline & $\begin{array}{c}\text { Height } \\
(\mathrm{cm})\end{array}$ & $\begin{array}{c}\text { Diameter } \\
(\mathrm{mm})\end{array}$ & $\begin{array}{c}\text { Leaf } \\
\text { emission (no.) }\end{array}$ & $\begin{array}{c}\text { Height } \\
(\mathrm{cm})\end{array}$ & $\begin{array}{c}\text { Diameter } \\
(\mathrm{mm})\end{array}$ & $\begin{array}{c}\text { Leaf } \\
\text { emission (no.) }\end{array}$ & $\begin{array}{c}\text { Height } \\
(\mathrm{cm}) \\
\end{array}$ & $\begin{array}{c}\text { Diameter } \\
(\mathrm{mm})\end{array}$ & $\begin{array}{c}\text { Leaf } \\
\text { emission (no.) }\end{array}$ \\
\hline \multicolumn{10}{|l|}{ Shading } \\
\hline $0 \%$ & $1.35 \mathrm{a}$ & 0.79 & 3.94 & 0.24 & 0.80 & 0.00 & 1.70 & 0.37 & 2.86 \\
\hline $30 \%$ & $0.82 a b$ & 0.39 & 2.33 & 0.34 & 0.69 & 1.38 & 0.65 & 0.33 & 2.25 \\
\hline $50 \%$ & $1.04 a b$ & 0.70 & 3.89 & 0.36 & 0.74 & 3.20 & 1.35 & 0.36 & 2.52 \\
\hline $70 \%$ & $0.75 \mathrm{~b}$ & 0.73 & 2.61 & 0.69 & 0.52 & 2.35 & 1.36 & 0.49 & 2.25 \\
\hline \multicolumn{10}{|l|}{ Leaf reduction } \\
\hline $0 \%$ & $1.24 \mathrm{a}$ & 0.90 & $2.88 \mathrm{~b}$ & 0.36 & 0.77 & 2.39 & 1.28 & 0.40 & 1.73 \\
\hline $50 \%$ & $0.95 \mathrm{ab}$ & 0.68 & $3.42 \mathrm{ab}$ & 0.80 & 0.33 & 2.33 & 1.78 & 0.52 & 2.77 \\
\hline $100 \%$ & $0.81 b$ & 0.45 & $4.16 \mathrm{a}$ & 0.24 & 0.80 & 0.00 & 0.76 & 0.24 & 3.08 \\
\hline
\end{tabular}

Only means followed by lowercase letters were significant by the $\mathrm{F}$ test. Means followed by the same letter um the column are considered as similar according to the Tukey test at $5 \%$ of significance. 
Therefore, the plants from this species placed under full sun demonstrated the highest mean growth in height at the end of six-month evaluation, while the seedlings under $70 \%$ shading had the lowest mean. Absence of leaf reduction resulted in a greater increase in plant height, while the $100 \%$ reduction resulted in the smallest increase in plant height (Table 1).

Possibly, since the species $C$. tomentosum is the only one among those studied which belongs to the initial phase of forest succession, it naturally tends to demonstrate a faster growth and less shading tolerance, thus justifying its greater increase in height observed under full sun, 30 and $50 \%$ shading (Table 1). Nevertheless, it must be emphasized that under $50 \%$ shading, in addition to height, the survival of this species was also enhanced (Figure 1), which means that it is possible to combine the good performance of both variables of interest under these conditions. A drop in the concentration of auxins and reserve sources may have caused the smaller increment in height, observed with the complete leaf removal of $C$. tomentosum, since the stimulus for stem elongation happens when the concentration of these mentioned substances increases (Raven et al., 2007).

Concerning the diameter increase, no shading $x$ leaf reduction interaction happened for any of the species, as well as a significant difference for the isolate factors (Table 1 ). In a similar fashion, Pierezan et al. (2012) found that the plant diameter did not differ statistically between the evaluated shading levels, 226 days after sowing.

When analyzing the emission of new leaves, there was no interaction between shading $x$ leaf reduction. Analyzing the factors alone, only for the species $C$. tomentosum there was influence of the leaf reduction factor, while the shading levels were similar. Therefore, there was greater emission of new leaves when performing the treatments of removing 50 or $100 \%$ of the leaf blades (Table 1 ).

Formation of new tissues by plants depends on both endogenous and exogenous factors and the interaction between them (Feliciana et al., 2017). Thus, in our study, the procedure of total or partial leaf removal possibly altered the endogenous balance between cytokinin and auxin, since the latter is mainly synthesized within these tissues. We believe that the increase in cytokinin concentration induced sprouting, and consequently, emission of a greater number of leaves in these treatments.

We know that native species show distinct behaviors and survival in response to the rescue (Viani \& Rodrigues, 2007; Viani et al., 2012). However, further studies are necessary in order to refine the technique for each species. It is noteworthy that the results of this study have great practical implications, since the survival of two out of the three studied species was enhanced under $50 \%$ shading, which is a widely used shading in commercial nurseries.

\section{Conclusions}

For rescue procedures of young plants of the Centrolobium tomentosum species, it is recommended using the $50 \%$ leaf reduction and acclimation of the individuals under $50 \%$ shading.

For rescuing young plants of the Hymenaea courbaril species, performing the leaf reduction procedure is not necessary and the recommendation is to place the individuals under $50 \%$ shading.

As for the species Copaifera langsdorffii, nor leaf reduction nor placing the plants under full sun is recommended, with the $70 \%$ shading as the one advised for use.

\section{Acknowledgements}

To the Coordination for the Improvement of Higher Education Personnel (CAPES) - Financing Code 001, the Federal University of Jequitinhonha and Mucuri Valleys (UFVJM) and to the Center of Studies in Recovery of Degraded Areas of UFVJM for the financial, logistics and intellectual supports.

\section{Compliance with Ethical Standards}

Funding: This work was supported by Conselho Nacional de Desenvolvimento Científico e Tecnológico (CNPq), Coordenação de Aperfeiçoamento de Pessoal de Nível Superior (CAPES) and Universidade Federal dos Vales do Jequitinhonha e Mucuri (UFVJM).

Conflict of interest: The authors declare no conflict of interest.

Author contribution: Conceptualization: IMP, MT; Formal analysis: GCS, MLRO; Investigation: LCAS, GCS; Supervision: IMP; Visualization: LCAS; Writing - original draft: LCAS, GCS, IMP; Writing - review \& editing: MAPS, MT.

\section{Literature Cited}

Almeida, R.F.; Sordi, S.J.; Garcia, R.J.F. Aspectos florísticos, históricos e ecológicos do componente arbóreo do parque da independência, São Paulo, SP. Revista da Sociedade Brasileira de Arborização Urbana, v.5, n.3, p.18-41, 2010. https//doi.org/10.5380/revsbau. v5i3.66301.

Brasil. Instituto Brasileiro do Meio Ambiente e dos Recursos Naturais Renováveis - Ibama. Instrução Normativa Ibama № 06, de 07 de abril de 2009. Dispõe sobre os procedimentos relativos às autorizações de supressão de vegetação em empreendimentos de interesse público ou social submetidos ao licenciamento ambiental pela Diretoria de Licenciamento Ambiental. Diário Oficial da União, v.146, n.67, seção 1 , p.82, 2009. https://futurelegis.com.br/legislacao/54790/ Instru\%C3\%A7\%C3\%A3o-Normativa-Ibama-N\%C2\%BA-06de-07-04-2009. 20 Aug. 2020.

Calegari, L.; Martins, S.V.; Busato, L.C.; Silva, E.; Coutinho Junior, R.; Gleriani, J.M. Produção de mudas de espécies arbóreas nativas em viveiro via resgate de plantas jovens. Revista Árvore, v.35, n.1, p.41-50, 2011. https://doi.org/10.1590/S010067622011000100005 
Dutra, T.R.; Grazziotti, P.H.; Santana, R.C; Massad, M. D. Desenvolvimento inicial de mudas de copaíba sob diferentes níveis de sombreamento e substratos. Revista Ciência Agronômica, v.43, n.2, p.321-329, 2012. http://www.ccarevista.ufc.br/seer/index. php/ccarevista/article/view/1334. 20 Sep. 2019.

Dutra, T.R.; Grazziotti, P.H.; Santana, R.C; Massad, M. D. Qualidade de mudas de copaíba produzidas em diferentes substratos e níveis de sombreamento. Floresta, v.45, n.3, p. 635-644, 2015. https:// doi.org/10.5380/rf.v45i3.35686.

Feliciana, A.M.C.; Morais, E.G.; Reis, E.S.; Corrêa, R.M.; Gontijo, A.S.; Vaz, G.H.B. Influência de auxinas e tamanho de estacas no enraizamento de azaleia (Rhododendron simsii Planch.). Global Science and Technology, v.10, n.1, p. 43-50, 2017. https://rv.ifgoiano.edu.br/periodicos/index.php/gst/article/ view/850/533. 13 Sep. 2019.

Klitgaard, B.B. Centrolobium in Lista de Espécies da Flora do Brasil. Rio de Janeiro: Jardim Botânico do Rio de Janeiro, 2015. http:// floradobrasil.jbrj.gov.br/jabot/floradobrasil/FB29512. 24 Sep. 2019.

Lima, H.C.; Pinto, R.B. Hymenaea in Lista de Espécies da Flora do Brasil. Rio de Janeiro: Jardim Botânico do Rio de Janeiro, 2015. http://floradobrasil.jbrj.gov.br/jabot/floradobrasil/FB22972. 24 Sep. 2019.

Moreira, F.M.S.; Siqueira, J.O. Microbiologia e bioquímica do solo. 2.ed. Lavras: Editora UFLA, 2006. 729p.

Pacheco, P.; Paulilo, M.T.S. Efeito da intensidade de luz no crescimento inicial de plantas de Cecropia glazioui Snethlage (Cecropiaceae). Insula, v.38, p.28-41, 2009. https://doi.org/10.5007/21784574.2009v38p28.

Pierezan, L.; Scalon, S.P.Q.; Pereira, Z.V. Emergência de plântulas e crescimento de mudas de jatobá com uso de bioestimulante e sombreamento. Cerne, v.18, n.1, p. 127-133, 2012. https://doi. org/10.1590/S0104-77602012000100015.

Queiroz, L.P.; Martins-da-Silva, R.C.V.; Costa, J. Copaifera in Lista de Espécies da Flora do Brasil. Rio de Janeiro: Jardim Botânico do Rio de Janeiro, 2015. http://floradobrasil.jbrj.gov.br/jabot/ floradobrasil/FB22896. 24 Sep. 2019.

R Core Team. R: A language and environment for statistical computing. Vienna: R Foundation for Statistical Computing, 2018. URL https://www.R-project.org/. 28 Aug. 2019.

Raven, P.H.; Evert, R. F.; Eichhorn, S. E. Biologia Vegetal. 7.ed. Rio de Janeiro: Guanabara Koogan, 2007. 830 p.

Reis, S.M.; Marimon-Júnior, B.H.; Morandi, P.S.; Oliveira-Santos, C.; Oliveira, B.; Marimon, B.S. Desenvolvimento inicial e qualidade de mudas de Copaifera langsdorffii Desf. sob diferentes níveis de sombreamento. Ciência Florestal, v.26, n.1, p.11-20, 2016. https://doi.org/10.5902/1980509821061.

Sá Júnior, A.; Carvalho, L.G. Application of the Köppen classification for climatic zoning in the state of Minas Gerais, Brazil. Theoretical and Applied Climatology, v.108, p.1-7, 2012. https://doi. org/10.1007/s00704-011-0507-8.

Sabino, M.; Korpan, C.; Ferneda, B.G.; Silva, A.C. Crescimento de mudas de ipês em diferentes telas de sombreamento. Nativa, v.4, n.2, p.61-65, 2016. https://doi.org/10.14583/2318-7670.v04n02a01.
Santos, A.C. Resgate de espécies endêmicas: estratégias para conservação da biodiversidade dos campos rupestres quartzíticos. Diamantina: Universidade Federal dos Vales do Jequitinhonha e Mucuri, 2018. 79p. Dissertação Mestrado. http://acervo.ufvjm. edu.br/jspui/handle/1/1899. 25 Aug. 2019.

Santos, G.C.; Silva, L.C.A.; Oliveira, P.A.; Vieira, E.R.D.; Pereira, I.M.; Oliveira, M.L.R.; Titon, M.; Farnezi, M.M.M. Rescue strategies for Xylopia sericea A.St.-Hil. plants from natural regeneration. Revista Brasileira de Ciências Agrárias, v.14, n.4, 2019. https:// doi.org/10.5039/agraria.v14i4a7028.

Silva, M.A.P.; Pereira, I.M.; Brito, L.A.; Costa, V.A.M. Aspectos ecológicos e silviculturais de Fabaceae da Mata Atlântica com potencial de uso na restauração florestal. In: Pereira, I.M. (Ed.) Restauração florestal da Mata Atlântica: aspectos ecológicos e silviculturais. Diamantina: UFVJM, 2018, p. 213-271.

Silva, N.F.; Pereira, I.M.; Silva, M.A.P.; Titon, M.; Oliveira, M.L.R.; Araújo, L.C.; Carlos, L. Potential production of Aspidosperma cylindrocarpon seedlings via rescue seedlings. Ciência Rural, v.47, n.5, e20141019, 2017. https://doi.org/10.1590/01038478 cr20141019.

Silva, N.F.; Pereira, I.M.; Titon, M.; Oliveira, M.L.R.; Laia, M.L.; Araújo, L.C. Resgate de mudas de Lychnophora pohlii como alternativa para recuperação e conservação de campo rupestre. Floresta, v.45, n.3, p.645-654, 2015. https://doi.org/10.5380/ rf.v45i3.31949.

Silvestrini, M.; Válio, I.F.M.; Mattos, E.A. Photosynthesis and carbon gain under contrasting light levels in seedlings of a pioneer and a climax tree from a Brazilian Semideciduous Tropical Forest. Brazilian Journal of Botany, v.30, n.3, p.463-474, 2007. https:// doi.org/10.1590/S0100-84042007000300011.

Viana, B.L.; Farias, W.W.; Nascimento, L.M.; Paulo, F.V.L.; Coêlho, C.B.; Falcão, C.J.L.M.; Silva, W.R. Produção de mudas de Xylopia frutescens Aubl. a partir da técnica de repicagem de plântulas da regeneração natural. Arrudea, v.1, n.2, p.34-46, 2015. http:// arrudea.recife.pe.gov.br/arrudea/index.php/Arrudea/article/ view/9. 03 Sep. 2019.

Viani, R.A.G.; Brancalion, P. H. S.; Rodrigues, R. R. Corte foliar e tempo de transplantio para o uso de plântulas do sub-bosque na restauração florestal. Revista Árvore, v.36, n.2, p.331-339, 2012. https://doi.org/10.1590/S0100-67622012000200014.

Viani, R.A.G.; Rodrigues, R. R. Sobrevivência em viveiro de mudas de espécies nativas retiradas da regeneração natural de remanescente florestal. Pesquisa Agropecuária Brasileira, v.42, n.8, p.1067-1075, 2007. https://doi.org/10.1590/S0100204X2007000800002.

Xavier, A.; Wendling, I.; Silva, R.L. Silvicultura clonal: princípios e técnicas. 2ed. Viçosa: UFV, 2013. 272 p.

Zimmermann, A.P.L.; Tabaldi, L.A.; Fleig, F.D.; Michelon, I.J.; Marangon, G.P. Métodos de transplantio para utilização de mudas de regeneração natural de Cordia trichotoma. Revista Brasileira de Ciências Agrárias, v.12, n.1, p.74-78, 2017. https:// doi.org/10.5039/agraria.v12i1a5416. 